\section{Magda Sučková}

Masaryk University,

Brno University of Technology, Czechia
2020, Vol. 17 (2), 83-100(284)

revije.ff.uni-lj.si/elope

https://doi.org/10.4312/elope.17.2.83-100

UDC: $811.111^{\prime} 242(437.3)$

\title{
Acquisition of a Foreign Accent by Native Speakers of English Living in the Czech Republic
}

\begin{abstract}
First language attrition has been shown to affect many areas of linguistic performance in immigrants to other countries. In phonetics, there is often a shift towards the majority language phonetic features, and, in some cases, the speakers may cease to be perceived as native altogether. This article presents the results of a foreign accent rating study, showing that even Anglophone expatriates are not immune to L1 attrition despite the (relative) lack of pressure to linguistically assimilate due to the status of their mother tongue as a prestigious and desirable-to-master language. The quantitative results are augmented by personal narratives of the expatriate informants, showing that what is often dismissed as mere anecdotal evidence may in fact bear a strong correspondence to the quantitative data.
\end{abstract}

Keywords: first language attrition, expatriates, native speakers of English, accent, intelligibility

\section{Usvajanje tujega naglasa pri rojenih govorcih angleščine, ki živijo v Republiki Češki}

\section{POVZETEK}

Dokazano je bilo, da izguba značilnosti prvega jezika vpliva na uspešno jezikovno rabo pri izseljencih $\mathrm{v}$ tujini. $\mathrm{V}$ izgovarjavi pogosto pride do premika $\mathrm{k}$ fonetičnim značilnostim večinskega jezika, in v nekaterih primerih govorci niso več dojemani kot domači. V članku so predstavljeni rezultati študije ocenjevanja tujih naglasov, ki kažejo, da tudi anglofonski izseljenci niso neobčutljivi za izgubo jezikovnih značilnosti svojega maternega jezika kljub (relativni) odsotnosti pritiska na jezikovno asimilacijo zaradi statusa njihovega maternega jezika kot prestižnega in zaželenega. Kvantitativni rezultati se dopolnjujejo z osebnimi pripovedmi tujcev, ki kažejo, da se anekdotični dokaz močno ujemajo s kvantitativnimi podatki.

Ključne besede: izguba prvega jezika, izseljenci, rojeni govorci angleščine, naglas, razumljivost 


\section{Introduction}

First language attrition, or "changes (usually a decline) in an individual's abilities in a language, induced by decreased use of and input in this language" (Bergmann, Nota, Sprenger, and Schmid 2016, 72), has been shown to manifest itself in many areas of linguistic performance (including phonetics) in immigrants to other countries (Schmid 2004, 2016).

The present investigation ${ }^{1}$ is concerned with first language attrition in the accent of Anglophone expatriates living in the Czech Republic. This particular population differs from other groups of immigrants in several respects, which are potentially preventive of $\mathrm{L} 1$ attrition (e.g. the high amount of L1 use, and low L2 use and proficiency). English is a prestigious language and Czech city dwellers typically have some knowledge of it; therefore, the pressure and need for the Anglophone expatriates to linguistically (and otherwise) assimilate is not as pronounced as with other immigrant groups. In fact, the opposite may often be the case in the Czech context, i.e. Czechs requiring the expats to communicate with them in English in order to practice this language. As a result, the L1 use rate is very high within this immigrant group (and can remain at $100 \%$ in the "expat bubble" in the capital). On the other hand, the source of L1 attrition for the Anglophone expatriates may well be the constant stream of "Czenglish" input, ranging in quality from heavily accented speech of beginner L2 English users, to the near-native-like speech of advanced ones. The speakers of American English may experience yet another influence on their L1, namely that of British English, as this variety is given preference in the Czech education system.

From the body of previous research (which I discuss below) and anecdotal accounts stem the following research questions I address in the present paper: Do the native speakers of English residing in the Czech Republic acquire a foreign, non-native sounding accent? Do they come across as more intelligible than the controls? Do the accents of American expatriates acquire a British flavour? And how well do the foreign accent rating (FAR) scores correspond to the personal narratives of the expatriates obtained in in-depth interviews concerning L1 attrition?

To obtain answers to these research questions I recorded three groups of participants retelling a short movie clip: a group of native speakers of English residing in the Czech Republic, ${ }^{2}$ a control group of native speakers of English living in England, and a control group of highly proficient Czech users of English. In line with the philosophy that accent is "in the ear of beholder", a group of assessors (highly proficient L2 users of English) listened to the speech samples and evaluated them in terms of the degree of foreign accentedness and intelligibility. I provide the full sample description and data collection procedure in the Method section of the present article. A thorough analysis of the quantitative data is then presented in the Results section. In order to obtain yet another perspective on the acquisition of L2 (Czech) accent, I conducted in-depth sociolinguistic interviews with the expatriate participants about their experience with L1 attrition (including the accent). I discuss these personal accounts and their relation to the quantitative data in the Narratives section.

1 The study represents a part of a PhD thesis supervised by Prof. Ludmila Urbanová at Masaryk University, Brno.

2 Henceforth referred to as expats or expatriates. 


\section{Review of the Literature}

Regarding L1 attrition in phonetics, empirical research shows there is often a shift towards the surrounding/majority language phonetic features, and, in some cases, the speakers may no longer be perceived as native. A compelling explanation why this may be so is offered by Flege's influential Speech Learning Model (Bergmann, Nota, Sprenger, and Schmid 2016; Flege 2002). This model posits the existence of a common phonological space in which the phonic elements of a bilingual's L1 and L2 interact with each other. If an L2 sound is identified by the L2 learner as being very similar to an L1 one, the two sounds are merged into a single category, and, as the L2 learner becomes more proficient, this merged category assumes a kind of intermediate value, a value which is different from both L1 and L2. This process is called phonetic category assimilation. The process of phonetic category dissimilation, on the other hand, is activated when an L2 sound is identified as different from an L1 sound and forms a distinct category in the phonological space. In order to maintain the L1 and L2 contrast, however, both L1 and L2 sounds drift away from the monolingual norms to more extreme positions (Flege 2002). This can, in fact, be seen as a form of hyper-correction. In other words, the Speech Learning Model hypothesises a bidirectional influence of L1 and L2 elements' phonetic characteristics (Bergmann, Nota, Sprenger, and Schmid 2016). These subtle changes in individual phonemes as well as overall prosody may over time result in some immigrants failing to be perceived as native speakers of their first language.

Let us now turn to the individual studies reporting phonetic L1 attrition (or cross-linguistic influence) in immigrants. On the level of phonetic detail, voice onset time (VOT, or the degree of aspiration) in fortis plosives is a particularly well-researched variable shown to be vulnerable to L1 attrition (Bergmann, Nota, Sprenger, and Schmid 2016). Flege (1987) demonstrated that Americans living in France displayed significantly shorter VOTs in their L1 (English) / $t /$ than the control groups living in the USA. Similar shortening of fortis plosive VOTs was observed by Major (1992) in Americans residing in Brazil. By contrast, Brazilian Portuguese fortis plosive VOTs lengthen upon a stay in the Anglophone environment, as was recently demonstrated in a study by Kupske and Alvez (2016). That the cross-linguistic influence on phonemes may be only of a temporary nature was suggested by Sancier and Fowler (1997). In their case study, they followed a single participant - a native speaker of Brazilian Portuguese with advanced command of English, as she alternated between Brazil and the USA, spending long stretches of time in each. The participant's plosives (in both languages) lengthened and shortened in accordance with the recent linguistic environment.

As regards a global foreign accent, or "the degree to which an L2 speaker's productions are perceived to differ from those of a native speaker" (Riney, Takada, and Ota 2000, 713), with which the present article is mainly concerned, there have not been many studies focusing on the acquisition of a foreign accent in one's first language to date (Bergmann, Nota, Sprenger, and Schmid 2016). In Sancier and Fowler's (1997) case study, mentioned above in connection with VOTs, their L1 Brazilian Portuguese informant's read utterances were judged to be more accented after she had spent several months in the USA. De Leeuw (2008) employed recordings of spontaneous speech and some of her sample of L1 German speakers living in the USA or in Netherlands were rated as sounding non-native-like. Similar results on both 
group and individual levels were reported in a recent study by Bergmann, Nota, Sprenger, and Schmid (2016) for native speakers of German residing in the USA and Canada. Hopp and Schmid (2013), on the other hand, found no difference on the group level between L1 German monolinguals and L1 German bilinguals living abroad. In a rather small-scale accent rating study (Sučková 2012) I reported some preliminary evidence suggesting there may be accent changes in Anglophone expatriates living in the Czech Republic. However, to the best of my knowledge, no other larger-scale foreign accent rating studies or accent intelligibility studies with English L1 attriters have been published to date (see also Bergmann, Nota, Sprenger, and Schmid 2016).

To summarise, signs of L2 influence on L1 pronunciation have been reported both on the level of individual phoneme characteristics and the overall accent impression. With respect to phonetic L1 attrition among native speakers of English living abroad, Flege (1987) and Major (1992) reported shortening of the VOTs in Americans living in France and Brazil respectively. Some preliminary findings and anecdotal evidence concerning changes in the global accent were reported in Sučková (2012). This study attempts to fill the gap in this area and thus provide a large-scale investigation of global foreign accent in Anglophone expatriates residing abroad, namely in the Czech Republic.

\section{Method}

\subsection{Speakers}

The sample of speakers consisted of three groups: L1 English expatriates living in the Czech Republic $(N=18)$, L1 English controls living in the UK $(N=16)$, and Czech controls $(N=$ 5) - advanced Czech users of English living in the Czech Republic.

Expatriates: 10 Americans and eight Britons (from various regions of the two respective countries), $M_{a g e}=38 S D_{\text {age }}=8.7$, raised in monolingual families, with a length of residence (LOR) in the Czech Republic of over one year $\left(M_{L O R}=9.5\right.$ years, $\left.S D_{L O R}=6.9\right)$, working mostly as teachers of English or in IT/corporate jobs, with varying degrees of L2 Czech proficiency. The sample were recruited through personal contacts of the researcher and via snowballing.

L1 English Controls: One American and 15 Britons recruited through opportunity sampling, $M_{\text {age }}=34, S D_{\text {age }}=12$, raised in monolingual families and living in the UK. The participants were not monolingual: they had all studied one or more foreign languages in the course of their lives; however, no participant was an early bilingual, and only four reported having a good or very good proficiency in one of their foreign languages and using them on a regular basis at the time of data collection.

Czech Controls: Five ${ }^{3}$ highly proficient Czech speakers of English living in the Czech Republic $\left(M_{\text {age }}=26, S D_{\text {age }}=3.3\right)$; the speakers had all been learning and using English since their early

Originally, there were six Czech controls. However, it later transpired from the notes on the rating questionnaires that the majority of the raters were able to identify one Czech control, having recognised her voice. Therefore, I decided to exclude the ratings obtained for this participant from the analysis and only present data for the five remaining Czech participants. 
childhood, had visited English-speaking countries, and reported using English for 20-85\% of their daily communication at the time of recording. The sample were recruited through personal contacts of the researcher.

\subsection{Procedure - Speech Samples for Foreign Accent Rating}

To elicit free speech data, the Charlie Chaplin task was utilised as described in Schmid (2011). The participants (the expatriates, the L1 English controls, the Czech controls) were asked to watch and then retell a short clip from Charlie Chaplin's 1936 motion picture Modern Times while being recorded. The recording sessions took place in a quiet university office or classroom, or at the informant's home.

From each recording a short sample was extracted for the accent rating. The speech samples all contained the description of the opening scene, in which Chaplin is being released from prison and applies for a job at a shipyard. The decision to include only one scene (as opposed to a random excerpt) was motivated by the need to standardise the samples as much as possible (de Leeuw 2008) and eliminate the possible intervening variable of surprise or confusion, and thus further cognitive strain on the part of the raters. The samples varied slightly in length (12-16 s) as it was decided, in accordance with de Leeuw (2008), to present naturally complete utterances and not cut the speaker off mid-sentence. In addition, pauses longer than $1 \mathrm{~s}$ were clipped and stuttered utterances edited out in several samples. This was motivated by the fact that while pauses and stuttered utterances may be indicative of L1 attrition in mental lexicon (Schmid 2011), they may also present confounding elements in otherwise perfectly native-like accent (de Leeuw 2008). In other words, a speaker's performance would potentially not be judged by their accent but by their inability to retrieve a word, which would be undesirable.

Finally, a single sound file (featuring all speech samples as described above, i.e. the descriptions of the opening scene) was created for the accent rating. The speech samples were pseudorandomised, each speech sample was included only once, and the order of the speech samples was the same for all raters. At the end of each speech sample, there were $14 \mathrm{~s}$ of silence in order to give the raters time to complete the corresponding entry. Two additional speech samples training samples - were added to the beginning of the file to help manage potential confusion and anxiety. The overall duration of the foreign accent rating sound file was $21 \mathrm{~min}$. As the speech samples featured varied considerably in maximum intensity peaks, the sound file was normalised utilising audio level adjusting software, The Levelator 2 (Sharpe et al. n.d.).

\subsection{Raters and FAR Questionnaire}

Raters: Eighty-seven university students or graduates of English language (64 females, 23 males; $M_{\text {age }}=23.7$ years, $S D_{\text {age }}=6.1, M O D_{\text {age }}=21$ ). The L1 of the raters was mostly Czech or Slovak; almost $60 \%$ of raters reported being near-native or native-like L2 users of English. While it would have been desirable to utilise L1 monolingual English speakers as raters, previous research has shown that L2 users of a language can reliably distinguish between native and non-native speakers of that language (Major and Baptista 2009). Furthermore, a high L2 users' interrater reliability was reported previously, indicating that L2 users perceive 
the level of foreign accent in a very similar way (Schmid and Hopp 2014). Regarding the difference between native monolingual and non-native bilingual (L2 user) raters, it appears that bilingual raters tend to judge monolingual native speakers as being more strongly accented than the native monolingual raters, and the ratings of $\mathrm{L} 1$ attrition group speakers and L2 user speakers do not differ (Schmid and Hopp 2014).

A FAR questionnaire (based on de Leeuw 2008) ${ }^{4}$ was created for the raters to assess the degree of global foreign accent of the speech samples. Figure 1 below shows the layout of the FAR questionnaire. Following de Leeuw (2008) and Schmid and Hopp (2014), the forced choice paradigm was utilised: the raters were asked whether the speaker is a native or non-native speaker of English, and how confident they were in their judgment on a three-point scale - certain, semi-certain, uncertain (Items 1,2). Item 3 was added to investigate the perceived intelligibility of a speaker and its potential relatedness to the level of global foreign accent. Less intelligible speakers may be considered "genuine native speakers" in the ears of L2 users, and vice versa. Additionally, Item 4 asked the raters to indicate where they think the speaker originally came from (thus revealing the potential Britishisation or Czechisation of native accents). Item 5 (optional) provided space for the raters to comment on how they arrived at their judgment and what they based it on. Lastly, at the very end of the questionnaire, the raters were asked to provide information about their age, gender, nationality, L1, and proficiency in English on a 1-6 scale $(1=$ complete beginner, $6=$ native-like).

\begin{tabular}{|l|l|l|l|l|l|}
\hline speaker & $\begin{array}{l}\text { 1) native } \\
\text { status }\end{array}$ & 2) confidence & $\begin{array}{l}\text { 3) easy or hard to } \\
\text { understand? }\end{array}$ & 4) country & notes \\
\hline speaker 1 & $\begin{array}{l}\square \text { native } \\
\square \text { non-native }\end{array}$ & $\begin{array}{l}\text { I am... } \\
\square \text { certain } \\
\square \text { semi-certain } \\
\square \text { uncertain }\end{array}$ & easy 123445 hard & & \\
\hline
\end{tabular}

FigURE I. Foreign Accent Rating (FAR) questionnaire layout

\subsection{Procedure - FAR Data Collection}

The majority of the raters listened to the Charlie Chaplin excerpts in one of several classroom group sessions; in addition, 12 raters were played the audio file on an individual basis. First, the researcher explained the aim of the study and described the structure of the questionnaire and the composition of the audio file. The raters were asked to fill in the questionnaire as they listened and not to worry if they missed a speaker or two. After a brief Q\&A session, the FAR audio file (as described above) was played either through loudspeakers to the whole group (in the group sessions) or through headphones (in the individual sessions). The order of the speech samples was the same for each rater. The raters were rewarded for their time and effort with extra credit towards their final grade in one of their phonetics-related courses (when applicable) or some candy.

Who, in turn, adopted Moyer's approach (1999, as cited in de Leeuw 2008). 


\subsection{In-depth Interviews - Qualitative Data}

I conducted semi-structured in-depth sociolinguistic interviews with the expatriates in order to obtain a more personal, qualitative perspective on the L1 attrition they may have been experiencing. The interviews were conducted together with the Charlie Chaplin data collection task. To obtain narratives on the potential accent changes, I asked the following questions: Has your accent changed in any way since you have moved to the Czech Republic? Has anybody (your friends or family members back at home) ever told you that you sounded different now? What dialect do you speak? Do you speak your native/regional dialect? I then obtained more details by asking follow-up questions, e.g. How did you feel? Do you think it's true? Why do you choose not to speak your native dialect?

The narratives were then transcribed and theme-coded with the aim of identifying recurring themes, emotions and attitudes. I analyse the themes in the Narratives section of the present article. One of the themes, the Britishisation of the English of American expatriates, was used to inform the Britishisation research question tested quantitatively in the FAR questionnaire.

\section{Results}

\subsection{FAR Scores}

Combining Items 1 and 2 of the FAR questionnaire provided a six-point Likert scale: " $6=$ certain of non-native speaker status, $5=$ semi-certain of non-native speaker status, $4=$ uncertain of non-native speaker status, $3=$ uncertain of native speaker status, $2=$ semicertain of native speaker status, $1=$ certain of native speaker status" (de Leeuw 2008, 50). In other words, a score of 6 means the rater perceived the speaker as having a strong nonnative accent, while a score of 1 indicates a perfect native-like accent. The scores obtained by the individual participants were averaged into a mean FAR score. Missing datapoints $(N=$ 18 , not systematically distributed) were substituted with scores closest to the speaker's mean FAR score. The descriptive statistics, including separate means for British and American expatriates, are provided in Table 1 below. Figure 2 below displays the boxplot of mean FAR scores for the three respective groups.

TABLE I. Mean FAR scores - descriptive statistics.

\begin{tabular}{|c|c|c|c|c|c|}
\hline & \multicolumn{3}{|c|}{ Expatriates } & L1 English & Czech \\
\hline statistics & Britons & Americans & pooled & pooled & \\
\hline$N$ & 8 & 10 & 18 & 16 & 5 \\
\hline$M$ & 3.38 & 3.76 & 3.59 & 2.99 & 4.41 \\
\hline$S D$ & 0.84 & 0.8 & 0.82 & 0.84 & 0.73 \\
\hline
\end{tabular}




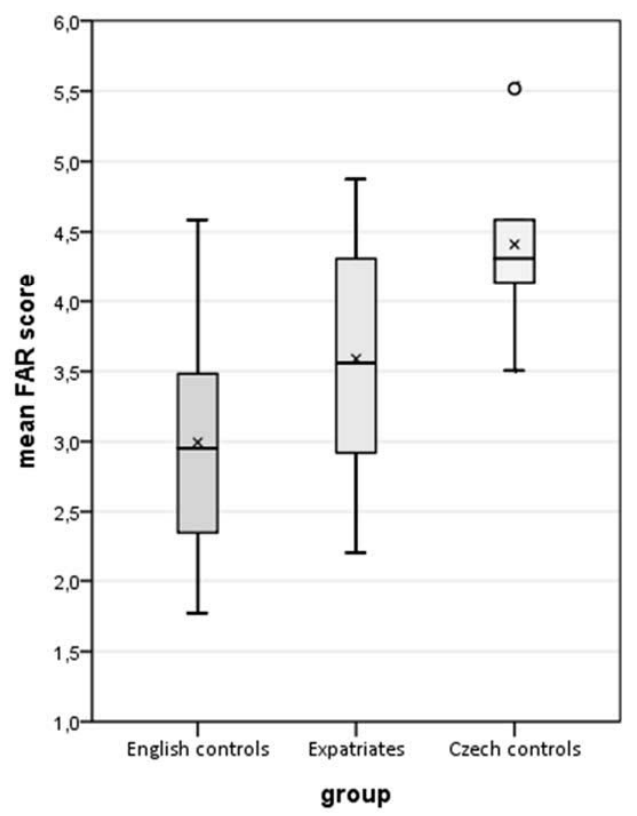

Figure 2. Boxplot of mean FAR scores.

From Table 1 and Figure 2 it can be observed that the control group exhibit the lowest FAR scores (i.e. the most native-like), followed by the expatriate group and then the Czech controls, who have the highest (i.e. the most non-native) FAR scores. Within the expatriate group, the Americans tended towards higher (i.e. less native-like) scores.

The distributions of mean FAR scores were examined for normality. The expatriates' FAR scores histogram showed a bimodal distribution, and the Czech control sample was too small to reliably assess the score distribution. Therefore, although all Shapiro-Wilk tests of normality were non-significant (all $p$ 's $>.4$ ), it was decided to utilise a non-parametric alternative to the t-test, namely the Mann-Whitney $U$ test, to determine whether the differences between the three groups are statistically significant. Further, as the British expatriates exhibited a slightly lower (i.e. more native-like) mean FAR score than the American expatriates, it was important to test whether the two groups are statistically different, in which case the country of origin would present a confounding variable. A Mann-Whitney $U$ test was conducted, showing no statistical difference between the two subgroups of the expatriate group (the mean ranks of the expatriate Britons and Americans were 8.1 and 10.6, respectively; $U=29, Z=-0.98, p=.36$ ).

Having established that the American and British expatriates do not exhibit statistically different mean FAR scores, a set of Mann-Whitney $U$ tests was conducted to establish differences between the expatriates, the L1 English controls, and the Czech controls. The significance level was Bonferroni adjusted to $\alpha=.017$. The test did not indicate a difference between the expatriates and L1 English controls (the mean ranks were 20.7 and 13.9 respectively; $\mathrm{U}=86.5, \mathrm{Z}=-1.98, \mathrm{p}=.046)$. Likewise, no difference was found between the expatriates and Czech controls (the mean ranks were 10.7 and 16.8 , respectively; $U=21, Z$ $=-1.8, p=.08)$. The only difference in mean FAR scores found to be statistically significant 
was between the Czech controls and L1 English controls (the mean ranks were 17.3 and 9.0, respectively; $\mathrm{U}=8.5, \mathrm{Z}=-2.6, \mathrm{p}=.006$ ).

Thus the hypothesis that the expatriates as a group have acquired a foreign accent as compared to the L1 controls was not supported. On the other hand, the tests also indicated that no difference existed between the mean FAR scores of the Czech controls and the expatriates. In such situations it is best to examine the data of individual participants. Figure 3 below shows the FAR scores of individual participants by group.

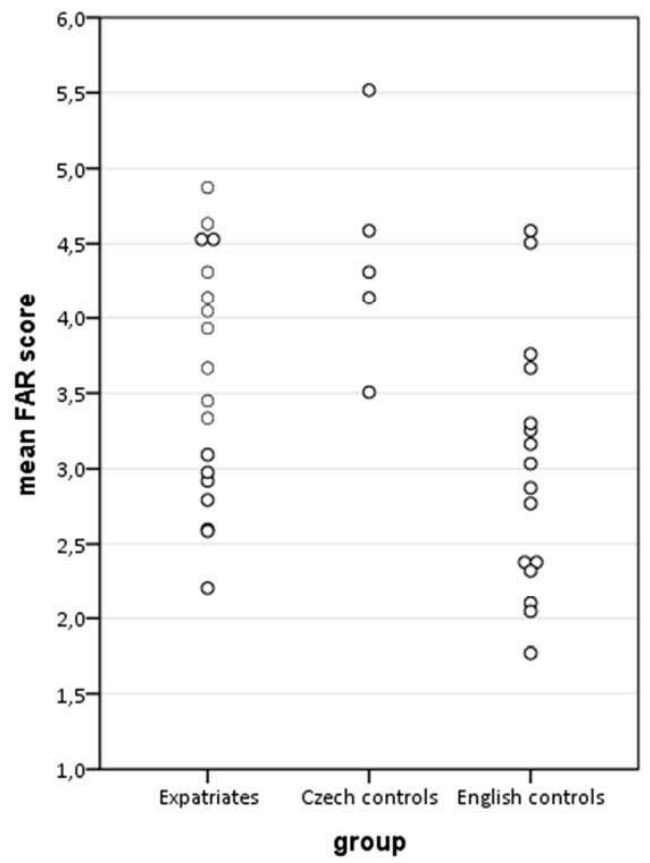

FIGURE 3. Individual mean FAR scores by group.

As can be observed, all expatriate scores are higher than the L1 English control minimum at 1.8. Only four (25\%) L1 English controls obtained scores in the Czech controls' range, as compared to nine (50\%) expats. If the Czech controls' score range is considered to be a benchmark of having acquired a (slight) foreign accent, then there are clearly expatriate informants whose accents do not appear to have been influenced, but also those who do sound like (very proficient) L2 users. With regard to the two extreme L1 English control participants who were also rated as having a foreign accent, one utilised a prominent hesitant rising intonation, which, according to the raters' comments in the FAR questionnaire led at least some to label this speaker's accent as non-native; the other L1 English control speaker with a high mean FAR score is the only American in this group, in fact a speaker living outside her native variety, which also might have given rise to a sort of "mixed" accent impression.

Overall, then, even though the hypothesis that the Anglophone expatriates have acquired a foreign accent into their L1 was not supported on the group level, high mean FAR scores indicate foreign accent acquisition in some individuals from the expatriate group. The degree 
of this foreign accent is comparable to that of highly proficient Czech users of English. This claim is further elaborated in the later section of the present article, which provides an analysis of the qualitative interview data.

\subsection{Intelligibility Scores}

To establish whether the expatriates' accent became more intelligible to the L2 users' ears, the raters were asked if they found the speaker easy or hard to understand on a five-point Likert scale: 1 (easy) -5 (hard) (Item 3 of the FAR questionnaire). For each participant, a mean intelligibility score was then calculated from the obtained ratings. The lower the mean intelligibility score, the greater the overall intelligibility. Figure 4 below shows a boxplot of the mean intelligibility scores for the three respective groups, while Table 2 provides the descriptive statistics, including those for the two subgroups (i.e. the British and Americans) of the expatriate group.

TABLE 2. Mean intelligibility scores - descriptive statistics.

\begin{tabular}{|c|c|c|c|c|c|}
\hline & \multicolumn{3}{|c|}{ Expatriates } & $\begin{array}{c}\text { L1 English } \\
\text { controls }\end{array}$ & $\begin{array}{c}\text { Czech } \\
\text { controls }\end{array}$ \\
\hline statistics & Britons & Americans & pooled & pooled & \\
\hline$N$ & 8 & 10 & 18 & 16 & 5 \\
$M$ & 1.73 & 1.78 & 1.76 & 1.91 & 1.42 \\
$S D$ & 0.45 & 0.41 & 0.41 & 0.35 & 0.14 \\
\hline
\end{tabular}

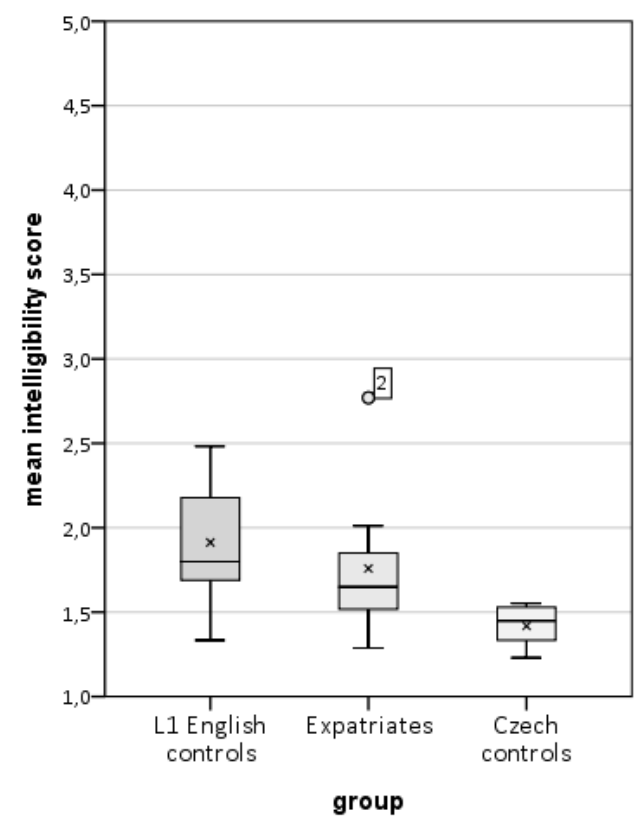

Figure 4. Intelligibility scores by group. 
As can be observed from Figure 4 and Table 2, the lowest intelligibility scores indicating the greatest intelligibility were obtained by the Czech control group, followed by the expatriates and then by the L1 English controls. Overall, the raters did not find any of the speakers to be very hard to understand. The British and American expatriates do not exhibit any big differences in their intelligibility scores; in fact, each of these subgroups features an outlier (as seen in Figure 4). The recordings of both expatriate speaker outliers in question feature relatively fast stretches of speech, with a high degree of word-linking. In addition, the American outlier expatriate's voice is somewhat "shaky", which may make him slightly harder to understand.

Next, the distributions of mean intelligibility scores were examined for normality. Both the expatriates' and L1 English controls' histograms showed a positive skew; in addition, the expatriates' Q-Q plot hinted at a deviation from the normal distribution. This was also supported by the result of a Shapiro-Wilk test of normality $(p=.001)$. The Czech control sample was too small to reliably assess the normality of mean intelligibility scores distribution. Therefore, it was decided to utilise a non-parametric alternative to the t-test, namely the Mann-Whitney $U$ test.

A set of Mann-Whitney $U$ tests was conducted in order to determine whether the differences between the three groups are statistically significant. The significance level was Bonferroni adjusted to $\alpha=.017$. The test did not indicate a difference between the expatriates and L1 English controls (the mean ranks were 14.8 and 20.6, respectively; $\mathrm{U}=94.5, \mathrm{Z}=-1.71$, $\mathrm{p}$ $=.088$ ). Likewise, no difference was found between the expatriates and Czech controls (the mean ranks were 13.6 and 6.1 , respectively; $U=15.5, Z=-2.2, p=.024$ ). The only difference in mean intelligibility scores that was found to be statistically significant was between the Czech controls and L1 English controls (the mean ranks were 4.3 and 13.1, respectively; U $=6.5, \mathrm{Z}=-2.8, \mathrm{p}=.003$ ). Thus, to the ear of (mostly) Czech and Slovak raters, advanced Czech users of English were the most intelligible group, there being no statistically significant difference between the two L1 English groups.

Of interest is the relationship between mean FAR scores and mean intelligibility scores: it is possible that the less intelligible speakers received more native-like ratings, and vice versa. The Kendall correlation, however, did not indicate any relationship between foreign accent and intelligibility (Kendall's $\tau_{B}=-.05, p=.65$ ). In other words, intelligibility does not seem to have played a role in the perception of speakers' global foreign accent.

\subsection{Country of Origin}

Item 4 of the FAR questionnaire inquired about the possible country of origin of the individual speakers. Two hypotheses were being tested with this: 1) Anglophone expatriates will be labelled as Czechs/Slovaks ${ }^{5}$ more often than L1 native controls; 2) American expatriates will

While the raters were mainly Czechs, there was also a number of Slovaks among them. The Slovakian accent in English does not differ greatly from Czech, there are many similarities. To an untrained ear, a proficient Czech speaker of English may sound undistinguishable from a proficient Slovak speaker. Slovak raters were more prone to award "Slovak" labels, possibly because their home country would be the first to come to mind. For these reasons it was decided to collapse the "Czech" and "Slovak" perceived country of origin labels into one category. Further, several instances of label "middle Europe" and "central Europe" were included in the cz/sk category as well. 
be labelled as British more often than British expatriates as Americans. These hypotheses were based on the following. Firstly, if the FAR scores indicate a difference between the groups, the expatriates must logically differ from L1 English controls in the perceived country of origin as well; and, if it is the case that the Czech accent was acquired, there would be more "Czech" or "Slovak" labels. Secondly, in the in-depth interviews American expats often claimed that their English had become Britishised, and the responses to Item 4 may confirm or reject this impression.

Figure 5 shows a bar chart for country of origin labels (in \%) awarded to expatriates and L1 English controls. The information provided by raters was coded in the following manner: 1 - hit (the speaker's country of origin was identified correctly), ${ }^{6} 2-\mathrm{cz} / \mathrm{sk}$ (Czech or Slovak Republic indicated as the country of origin), 3 - empty (no country of origin provided), 4 other English-speaking country (i.e. not the actual Anglophone country of origin), 5 - other (any other country).

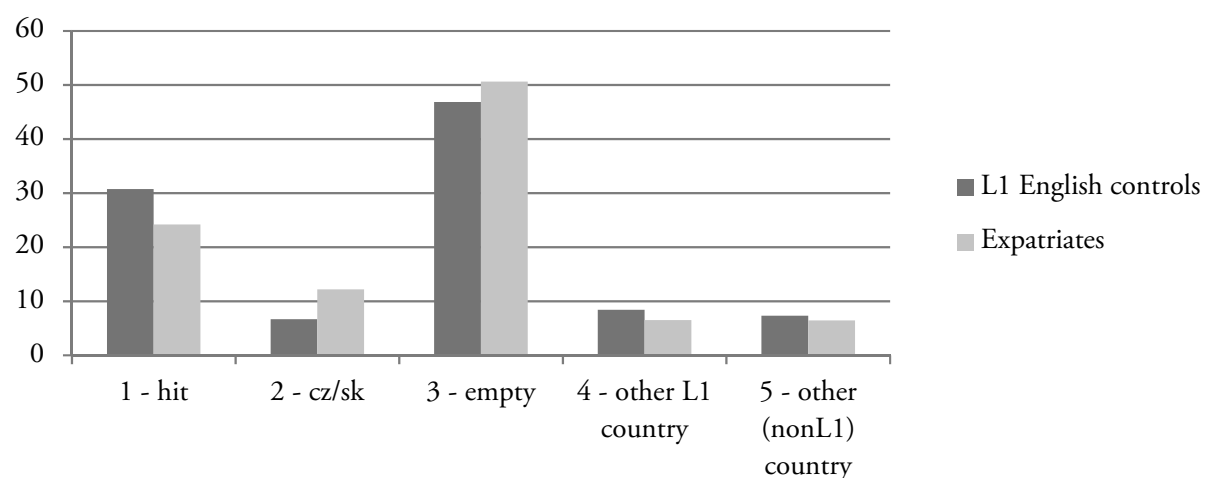

Figure 5. Country of origin as guessed by the raters in \%.

The bar chart indicates that it was often difficult for the raters to guess the country of origin of the speaker, as no country was provided almost $50 \%$ of the time (this also holds for the Czech control group whose data, however, are not included in the chart). Regarding the differences between the two Anglophone groups, the only one that is salient is the percentage of hit and cz/ sk labels, with expatriates (represented by lighter bars) receiving slightly more cz/sk labels (and, in turn, fewer hits and other L1 country labels) than the L1 English controls (darker bars). These results are in keeping with the mean FAR score pattern, in which some expatriates were perceived as more non-native (i.e. received a higher mean FAR score) than the L1 controls.

Another bar chart (Figure 6) was constructed to visualise the differences between British and American expatriates with regard to the perceived country of origin. The purpose of this analysis was to investigate whether the raters perceived any Britishisation in the accents of American expatriates. Three (slight) differences can be observed: firstly, Americans (represented by the darker bars) were identified correctly slightly more often than the British (lighter bars); secondly,

\footnotetext{
Canada and the USA were collapsed into one category for the purposes of this analysis, as American and Canadian accents may be very similar in many instances.

7 For the purposes of the present analysis, only Kachru's (e.g. 1990) Inner Circle countries (i.e. the UK, USA, Canada, Ireland, New Zealand, Australia and South Africa) are included under this label.
} 
they received fewer inaccurate Anglophone labels; and thirdly, Americans were more frequently considered to be Czechs than their British counterparts. These results do not indicate that the English of American expatriates has become Britishised. The fact that the Americans received more cz/sk and non-L1 country of origin labels is in keeping with the slight (and statistically non-significant) difference in British and American expatriates' mean FAR scores.

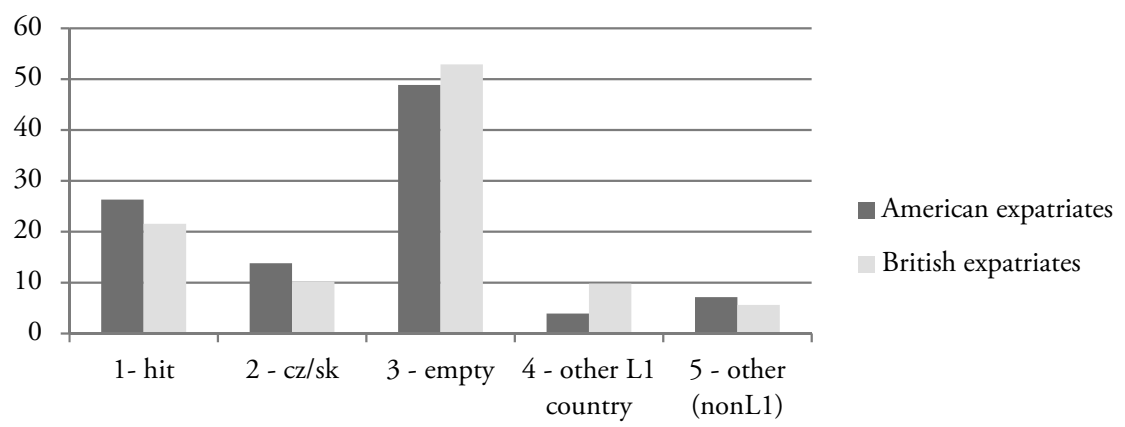

Figure 6. British and American expatriates' perceived country of origin in \%.

The hypothesis based on personal accounts of the American expatriates that their L1 is becoming Britishised was not supported by the data from this accent rating study. In fact, it was the British accents that were slightly more difficult to identify for the raters. However, as can be seen from the charts in Figs. 5 and 6, 50\% of the time no country of origin was provided by the raters. This can be interpreted in several ways. The raters may have been short of time (despite the fact that the questionnaire had been piloted and adjusted accordingly in order to prevent this), may have lacked confidence (despite the study being anonymous), may have genuinely been at a loss as to where the speakers came from, or a combination of all of the above. Clearly, fewer missing data would have been desirable in order to draw firmer conclusions.

\section{Narratives}

The idea for this research started several years ago when a friend of the researcher from the expat community remarked that he spoke "like Dracula, too", comparing himself to another expat who had arrived a couple of years earlier. All too often researchers are guilty of brushing personal stories similar to this one aside as mere "anecdotal evidence", or, on the other extreme, relying solely on personal narratives without employing more objective quantitative methods of enquiry. This section presents an attempt to interconnect the personal narratives of the expatriate informants obtained through the in-depth socio-linguistic interviews with the quantitative foreign accent rating study results, which were presented above.

One of the most frequently recurring themes, mentioned by almost all expatriate informants, was the need to slow down and speak more clearly, "enunciate", in order to be more easily comprehended by the Czech users of English, including co-workers, students, and their partners' families. However, this does not seem to be mirrored in the results reported above, as the expatriates were not rated to be more easily intelligible than the L1 English controls. There are at least two possible explanations for this. Firstly, the sample of raters was comprised 
of university students or graduates of English, i.e. above-average users of L2 English, who can easily comprehend "unmodulated" speech. And secondly, it is possible that the L1 English control participants actually modulated their speech in the same way as the expatriates in the formal context of being recorded by a non-native speaker for an audience of non-native speakers. In fact, a t-test conducted to compare the speech rates (operationalised as words per minute) of Charlie Chaplin clip retellings revealed no difference between the expatriates and L1 English controls $(t(32)=0.39, p=.7)$. The third possibility is, of course, that the expatriates only imagine slowing down, but actually do not, or that they wished to present themselves as helpful and forthcoming conversation partners; this, however, does not seem plausible since it would objectively lead to communication difficulties (as some expatriates discovered soon upon arrival).

Another theme that came up frequently was abandoning the local dialect in favour of Standard British or General American for the same reason as above - to be more intelligible to the L2 users who may not be familiar with many regional varieties. As one informant remarked about her accent, "It's lost a lot of colour, like local colours are kind of washed out". The American expats sometimes said that they felt their English was becoming Britishised ("I still sound like textbooks, except it's New English File," said participant EG04," an American teacher of English). However, the examples of such Britishisation provided by the informants were predominantly from the domain of lexis, not phonetics. This showed in the FAR study results: there was no wholesale mistaking Americans for British (although it should again be noted that in about $50 \%$ of cases the raters did not provide any guess as to the country of origin). Participant EG14, another American expat teacher of English, commented thusly on the status of American English: "One Czech will feel that British English is more proper, which it isn't [...], the other one will feel that American's more money. So [...] I'll get jobs because they feel that by speaking American they'll get some kind of um I don't know um business acumen". One's dialect is thus seen as influencing one's job opportunities, based on the students' preferences, but there seems to be market for both varieties. It is worth noting here that most interviews were conducted before the Brexit referendum, and it is unclear what impact this major event might have had upon the students' preferences.

Finally, six out of 18 expat informants recalled an occasion when they were told by a family member, friend, or complete stranger that they do not sound native-like. Additionally, three informants remembered an occasion when they had been identified as coming from a different English-speaking country (EG07: "I sound native. But sometimes people were just confused about what native I am."). EG12, an American teacher of English and an editor, told the following story: "There was another time, when I was having lunch, that I was speaking on the phone in English, and some old man - I told you about this - some man came up and yelled at me. And he was like 'Speak Czech!' like he thought I was Czech and I was putting on airs speaking English, like 'What do you,' you know, 'speak your native language!' And I told him I'm not Czech, I'm from America, and he didn't believe me." This story was related as one would tell an anecdote, with a lot of laughter, exaggerated gestures and facial expressions,

\footnotetext{
8 A popular British English series of textbooks.
}

9 Expatriate Group participant nr. 4. 
and with several repetitions of what the stranger had said. This humorous attitude to and amusement at one's first language attrition experiences (see also EG04's New English File comment above) emerged as a common pattern in the narrative data, and can be interpreted as a coping strategy in the face of a potentially threatening situation, as has been described by psychologists (e.g. Martin 2007 for an overview).

Not all narratives carried an element of humour, however; some contained a sense of irritation. EG13's story is in stark contrast to that of participant EG12 quoted above. Participant EG13 had been "accused a couple of times of being Danish, Scandinavian". When I commented on the use of the word 'accused', she added, "Well, because I'm obviously not and it's just really weird". Her story also contains one interesting detail. Unlike EG12 (who, in fact, provided the only narrative where it was implied he had a Czech accent), EG13 had been told she had an accent of a different country than the Czech Republic. Typically, however, the informants had their accent described in much less specific way: they sounded "somewhat oddly", spoke "different", their accent had "changed a little bit". Some, like the British expatriate EG05, had been asked where they had learned their very good English, which implies that the interlocutors did not consider the informant to be a native speaker of the language, but merely a very successful learner.

These narratives of having acquired a non-native accent systematically complement the quantitative data: the informants with stories of a perceived change in accent cluster within the

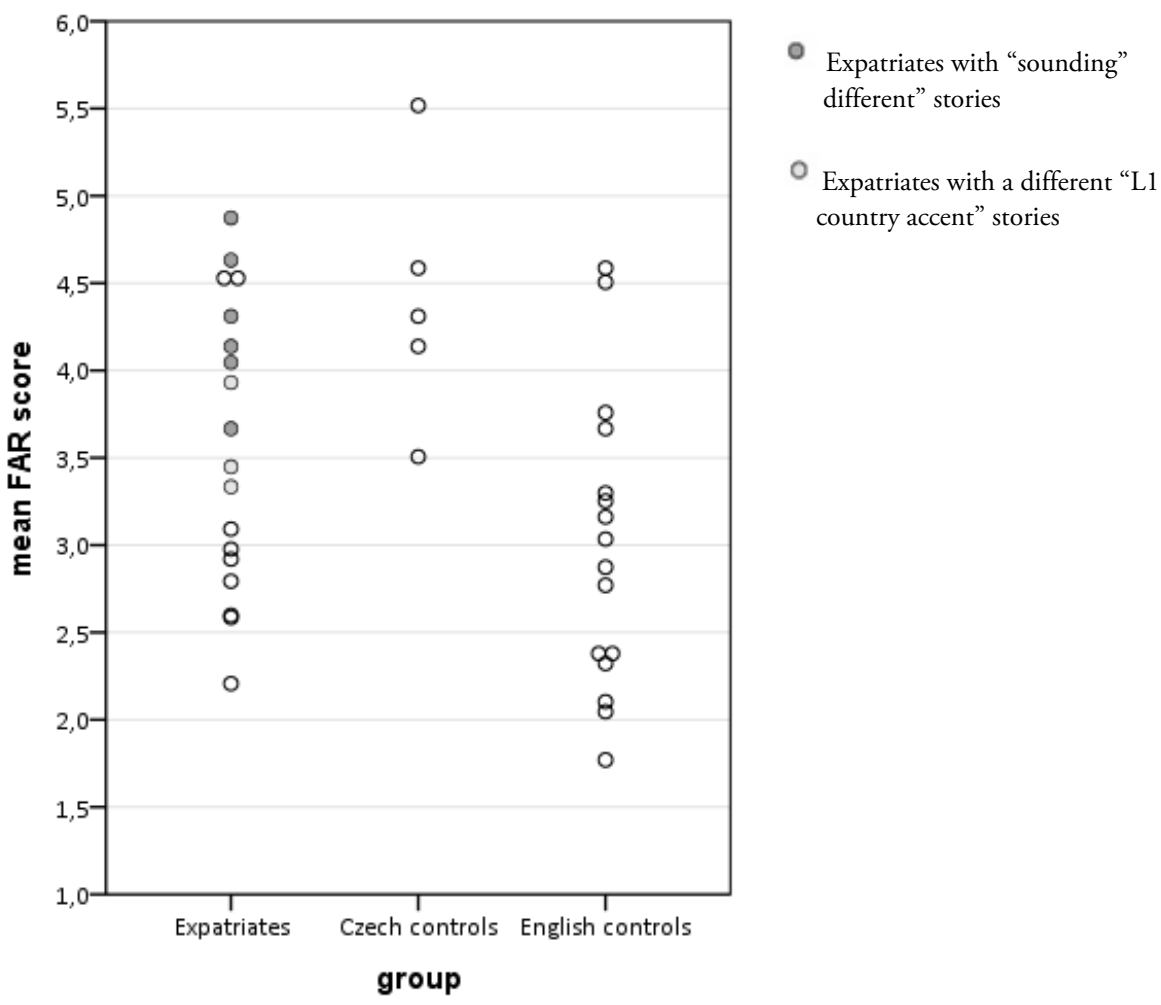

FigURE 7. Individual mean FAR scores and the qualitative data. 
Czech controls' FAR score range, and no participant with the FAR score lower than 3.3 had any such experience. This is illustrated in Figure 7 below, showing individual FAR scores for the three groups and highlighting informants with $\mathrm{L} 1$ attrition stories. The fact that the expatriate participants who have received comments hinting at $\mathrm{L} 1$ attrition tend to receive higher FAR scores supports the claim that even though statistically there is no difference between the expatriate and L1 English control groups as to the degree of perceived foreign accentedness, at least some expatriate informants have indeed acquired a degree of a foreign accent.

\section{Discussion}

The aim of the present article was to investigate three hypotheses regarding the accents of Anglophone expatriates living in the Czech Republic, namely that: (a) the expatriates acquired a slight foreign accent in their L1; (b) the American expatriates acquired a British accent; and (c) that the English of the expatriate participants has become more intelligible as compared to the controls. In order to test these hypotheses, a foreign accent rating experiment was conducted, whereby a group of raters listened to the recordings of the expatriates and two control group participants (L1 Czech controls and L1 English controls) and assessed them in terms of the degree of foreign accent, intelligibility, and perceived country of origin. These quantitative data were then complemented with qualitative data obtained through in-depth interviews with the expatriate participants.

With regard to the first hypothesis, that the expatriates acquired a foreign accent in their L1 English, or in other words that they exhibited signs of L1 attrition in their accent, this was not supported at the group level, with the difference between the expatriates' and L1 controls' mean FAR scores not being statistically significant. At the same time, there was a statistically significant difference between the Czech controls and L1 English controls, but not between the expatriates and Czech controls, hinting at the lack of statistical power of the tests under Bonferroni correction. Thus, it may be speculated that with a bigger sample size of both the expatriates and raters, the statistical tests would potentially reach significance. The fact that the raters were L2 users of English has also undoubtedly influenced the resulting FAR scores (for a detailed discussion see Schmid and Hopp 2014). However, the complementary expatriates' narratives showed that the participants who in the past had been told that their accent had changed received higher mean FAR scores which were within the Czech control range. Those who did not report any such experience also received lower (i.e. more native-like) ratings. These facts lend support to claim that at least some participants exhibit changes in their accent that may to ears of some (be it their family and friends or the raters in the experiment) sound foreign.

The country of origin data obtained using FAR questionnaire did not support the hypothesis that the accent of American expatriates became Britishised under the influence of the preferred dialect (i.e. Standard British English) in the host country. The changes towards British English (if any) possibly remain predominantly on the level of lexicon.

Finally, although slowing down and enunciating for the sake of the L2 interlocutor were a frequently recurring theme in the expatriates' narratives, the FAR questionnaire data did not indicate any greater intelligibility of the expatriates' accents as compared to the L1 controls. There may be several explanations for this disagreement of qualitative and quantitative results. 
Firstly, there was a statistically significant difference between the Czech control group and the L1 English controls, but not between the Czech controls and the expatriates, which suggests the lack of statistical power of the test utilised under Bonferroni correction. Secondly, both groups knew there would be a further audience (i.e. the raters in the foreign accent rating experiment), so both could have accommodated in the same manner towards this. What should be also taken into consideration is the advanced level of English of the raters, who found all speech samples rather easy to understand, which created a kind of ceiling effect. It may be speculated that the three groups would be better distinguished in terms of intelligibility with lower proficiency raters. Finally, there is the possibility that the expatriates believe that they do accommodate towards the less proficient Czech users of English (the "subjective dimension of accommodation", as proposed by Thakerar, Giles, and Cheshire, and cited in Platt and Weber 1984), but in fact they do not ("objective dimension of accommodation"). This, however, does not seem plausible, as it would objectively give rise not only to the inability to get the message across, but also of coming across as disrespectful, arrogant, and rude, as was implied by several expatriates in the qualitative interviews.

The present study is not without shortcomings. The L1 English informants and the expatriates were not matched with regard to several socio-demographic variables, country of origin being the most glaring one. Further, some informants had only spent a relatively short time in the Czech Republic in comparison to that needed for the effects of L1 attrition to fully develop. In addition, bigger sample sizes and greater homogeneity in terms of length of residence would certainly have been desirable in order to draw firmer conclusions. Unknown remain the possible effects of self-selection bias, given the relative difficulty of participant recruitment: the volunteering informants may have either suffered more L2 influence/L1 attrition (and therefore volunteered to participate, feeling they had "something to say" on the topic) or a lesser amount thereof (and therefore felt less vulnerable to volunteer). Finally, having native speakers as raters would possibly have led to slightly different results (as demonstrated in Schmid and Hopp 2014).

In order to provide a different, more personalised angle and to partially compensate for the shortcomings listed above, the quantitative data analyses were augmented with a qualitative analysis of the expats' narratives, which showed a good degree of correspondence to the FAR score data, thus supporting the hypothesis that some participants have acquired a slight foreign accent while living and working in the Czech Republic. The narrative data also showed emotions associated with this phenomenon, namely amusement and sometimes irritation.

\section{Conclusion}

First language attrition is a fascinating (and still understudied) area in the field of bilingualism. In this paper, I presented evidence suggesting that even Anglophone expatriates, who are able to use their L1 on daily basis and do not need to acquire the $\mathrm{L} 2$ of the country of residence, are not completely immune to it, at least on the phonetic level. The questions that remain open for future investigations include which factors are facilitative of $\mathrm{L} 1$ attrition in this population (in particular what role the amount of Czenglish input plays), and which factors help prevent it. 


\section{References}

Bergmann, Christopher, Amber Nota, Simone A. Sprenger, and Monika S. Schmid. 2016. "L2 Immersion Causes Non-Native-Like L1 Pronunciation in German Attriters." Journal of Phonetics 58: 71-86. https://doi.org/10.1016/j.wocn.2016.07.001.

Chaplin, Charlie, dir. 1936. Modern times. Leipzig: Kinowelt Home Entertainment, 2010. DVD.

Flege, James Emil. 1987. "The Production of "New" and "Similar" Phones in a Foreign Language: Evidence for the Effect of Equivalence Classification." Journal of Phonetics 15 (1): 47-65. http://www .jimflege.com/files/Flege_new_similar_JP_1987.pdf.

—. 2002. "Interactions Between Native and Second-Language Phonetic Systems." In An Integrated View of Language Development: Papers in Honor of Henning Wode, edited by Petra Burmeister, Thorsten Piske, and Andreas Rohde, 217-44. Trier: Wissenschaftlicher Verlag Trier.

Hopp, Holger, and Monika S. Schmid. 2013. "Perceived Foreign Accent in First Language Attrition and Second Language Acquisition: The Impact of Age of Acquisition and Bilingualism." Applied Psycholinguistics 34 (2): 361-94. https://doi.org/10.1017/S0142716411000737.

Kachru, Braj B. 1990. "World Englishes and Applied Linguistics." World Englishes 9 (1): 3-20. https://doi .org/10.1111/j.1467-971X.1990.tb00683.x.

Kupske, Felipe Flores, and Ubiratã Kickhöfel Alves. 2016. "A fala de imigrantes brasileiros de primeira geração em Londres como evidência empírica para a língua como um Sistema Adaptativo Complexo.” Revista Virtual de Estudos da Linguagem-ReVEL 14 (27): 173-203. http://www.revel.inf.br/files/e166bf 461 eec067bb8459c6617d5fd52.pdf.

Major, Roy C. 1992. “Losing English as a First Language.” The Modern Language Journal 76 (2): 190-208. http://dx.doi.org/10.2307/329772.

Major, Roy C., and Barbara O. Baptista. 2009. “First Language Attrition in Foreign Accent Detection.” In Recent Research in Second Language Phonetics/Phonology: Perception and Production, edited by Michael A. Watkins, Andreia S. Rauber, and Barbara O. Babtista, 256-69. Newcastle upon Tyne: Cambridge Scholars Publishing.

Martin, Rod A. 2007. The Psychology of Humour: An Integrative Approach. Amsterdam: Elsevier.

de Leeuw, Esther. 2008. "When Your Native Language Sounds Foreign: A Phonetic Investigation into First Language Attrition.” PhD diss., Queen Margaret University Edinburgh.

Platt, John, and Heidi Weber. 1984. "Speech Convergence Miscarried: An Investigation into Inappropriate Accommodation Strategies." International Journal of the Sociology of Language 1984 (46): 131-46. https://doi.org/10.1515/ijsl.1984.46.131.

Riney, Timothy J., Mari Takada, and Mitsuhiko Ota. 2000. "Segmentals and Global Foreign Accent: The Japanese Flap in EFL.” Tesol Quarterly 34 (4): 711-37. https://onlinelibrary.wiley.com/doi/pdf/10 $.2307 / 3587782$.

Sancier, Michele. L., and Carol A. Fowler. 1997. "Gestural Drift in a Bilingual Speaker of Brazilian Portuguese and English.” Journal of Phonetics 25 (4): 421-36. https://doi.org/10.1006/jpho.1997 .0051 .

Schmid, Monika S. 2004. "Language Attrition Research: An Annotated Bibliography." In First Language Attrition: Interdisciplinary Perspectives on Methodological Issues, edited by Monika S. Schmid, Barbara Köpke, Merel Keijzer, and Lina Weilemar, 317-48. Amsterdam: John Benjamins Publishing.

—. 2011. Language Attrition. Cambridge: Cambridge University Press.

—. 2016. "First Language Attrition." Language Teaching 49 (2): 186-212. https://doi.org/10.1017 /S0261444815000476.

Schmid, Monika S., and Holger Hopp. 2014. "Comparing Foreign Accent in L1 Attrition and L2 Acquisition: Range and Rater Effects." Language Testing 31 (3): 367-88.

Sharpe, Bruce, Malcom Sharpe, Norman Lorrain, Russell Heistuman, and Doug Kaye. n.d. The Levelator ${ }^{\circ}$ 2, Vers. 2.1.1. http://www.conversationsnetwork.org/levelator.

Sučková, Magda. 2012. "Phonetic Changes in the Speech of Anglophone Expatriates." MA thesis, Masaryk University. 